\title{
The Political Unity of EUROPE: A DREAM, OR A REALITY IN THE MAKING?
}

\author{
Mario Patrono*
}

"It is difficult to make predictions, especially about the future.” Oscar Wilde

The political unity of Europe is something that most people today see as purely hypothetical, or at the very least, remote: the future appearance on the world stage of a Europe unified politically as well as economically; a Europe that will at last have become a unitary political entity. Many (but not the author) exclude it from the ambit of current political possibility. For some, it is desirable; for others, frightening. This paper considers the "when", and the "if", of European unification questions to which the eventual coming into force of the Treaty establishing a Constitution for Europe, the text of which was agreed toon 18 June 2004, does not provide an answer.

L'unification politique de l'Europe est un événement que la plupart des gens regardent comme purement hypothétique ou dont l'avènement ne devrait se réaliser que dans un avenir lointain: l'entrée sur la scène mondiale d'une Europe unifiée politiquement aussi qu'économiquement; une Europe qui sera finalement une entité politique unitaire. Beaucoup l'excluent complètement comme possibilité politique actuelle. Pour les uns, il est désirable; pour les autres, effrayant. Cet article considère les questions «quand», et «si», en ce qui concerne l'unification européenne, questions auxquelles i'entrée en vigeur éventuelle de la traité établissant une constitution européenne, agréé le 18 juin 2004, ne répond pas.

The study undertaken here falls within the sphere of "predictive jurisprudence" as defined by Giuseppe Guarino. ${ }^{1}$ "There are", Guarino explains, "two levels on which to place oneself when 'doing law': that of the jurist who applies, and that of the jurist who proposes". An exercise of the

* $\quad$ Professor of Public Law, University of Rome I; regular visitor to the Victoria University of Wellington Law School. This paper, translated from the Italian by Andrew Townend, is an edited version of the preface to Professor Patrono's recent book Il Governo della Prima Europa (Cedam, Padua, 2003).

1 Giuseppe Guarino "È Proponibile una Scienza Giuridica Predittiva?" [1995] 1989 Riv Dir Pubbl Sc Pol 413-423. 
latter sort draws not only on personal intuition, but also on acquired experience, and in my case on the conviction that any prediction of the constitutional structure of the united Europe should be based on its actual development over time, rather than on ideas from the past or ideological prejudice.

Let us consider the questions of when and whether the political integration of Europe will be achieved. From a legal point of view, determining when the process of integration of the states that currently make up the European Union (EU) will be completed raises a problem, the solution to which is anything but simple.

When will the united Europe come into being? The first answer that springs to the mind of the constitutional lawyer is this: the emergence of a united Europe will occur upon the transformation of the treaty that binds the member states of the European Community (EC) into a true federal constitution - or more exactly, into the constitution of a federal European state - at which point the states themselves will completely abandon their own independence. If this answer were correct, it would simplify everything.

But an answer of this kind (apparently the only one possible, if a constitutional lawyer is to give it) is doubly flawed: first, when it describes the process of integration by reference to legal structures - a federal constitution, a federal European state - that Europe will probably never have, without the process of political integration (if it happens) being impeded by them. When I was a law student at the University of Rome, a great professor of mine, Riccardo Orestano, taught me that legal concepts are a bit like drugs: those that are targeted to the condition do good, and the others bad; because concepts, like drugs, have a high cost: for drugs, a biological cost; for concepts, the risk of not understanding how things are in reality, especially if that reality is a completely new one.

Why do I say this? For the very simple reason that I consider it an error, in interpreting the process of European integration, to look back at federal or confederal models of the past. Life moves forever ahead; new situations emerge all the time. The present situation is completely new: we have never before seen, for example, an integration where a single market and economic and monetary union do not follow political unity but precede it, and maybe even overshadow it. It seems to me, therefore, that when we consider the way in which European integration presents and will present itself, the confederation/federal state dichotomy need not concern us, or need only concern us indirectly and for the purposes of contrast. ${ }^{2}$

Let us consider the current situation. The launch of the euro on 1 January 2002 was the culmination of a historical experiment of great economic and legal importance, which began in 1957

2 The traditional view finds its origins in Franz Neumann ("On the Theory of the Federal State" in Herbert Marcuse (ed) The Democratic and the Authoritarian State: Essays in Political and Legal Theory (Free Press, New York, 1957) 216, 229): "[I]f one decides that one must go beyond confederation and yet maintain the existing state structure, obviously only the federal state remains as a possibility." Neumann maintained this thesis even before the Treaty of Rome had been signed. 
with the Treaty of Rome: the voluntary delegation by sovereign states to a supranational organisation, the EC, of the hugely ambitious task of building a single market among European countries. Six members at first; 25 now, following the Treaty of Copenhagen of 13 December 2002 and the admission of 10 members on 1 May 2004; and a further two, Romania and Bulgaria, in 2007.

Naturally, the market which is now manifested in the EU could not have reached such a high level of integration (but would have eventually become much weaker and more fragmented) if economic integration had not been accompanied by a similarly high degree of legal integration. This second sort of integration has been the work of community institutions - in particular, the Court of Justice and the Commission - and to a lesser extent of the founding Treaties, which themselves contain a unifying impulse.

In crude terms, EC law - unlike that of "classical" confederations - reaches into the domestic legal systems of the member states and acts directly as a regulator of interpersonal relations, and as a source of law that domestic courts and bureaucracies are bound to apply, even in the face of incompatible domestic law (including incompatible constitutional and human rights norms). ${ }^{3}$ Both derived from the founding Treaties, these two intertwined elements of community law - its supremacy and direct effect - have been joined by a third: the binding power of interpretation of the European Court of Justice, which now makes it the final arbiter of national as well as Community laws. ${ }^{4}$

The interplay of these three elements represents the legal aspect of the single market: a body of individual rights and liberties in constant fermentation; rights and liberties protected by the EC legal system. Community norms - said the Court of Justice in 1978 - are "a direct source of rights and duties for all those affected thereby, whether Member States or individuals, who are parties to legal relationships under Community law". ${ }^{5}$ It should immediately be added, to complete the description, that the legal system of the EC guarantees the protection of fundamental rights, at least to the extent that an essential nucleus of such rights forms part of the "general principles of law protected by the Court of Justice". 6 In the Court's view, this nucleus of rights is derived, first, from the "constitutional traditions common to the Member States",7 and, secondly, from the provisions of the

3 See the judgment of the European Court of Justice in Case C-285/98 Tanja Kreil v Bundesrepublik Deutschland [2000] ECR I-69, on the similar conclusions of Advocate-General La Pergola.

4 See A La Pergola "La Corte di Giustizia 'Comune"' in Atti dell'Incontro di Studio tra la Corte Costituzionale e la Corte di Giustizia delle Comunità Europee (Rome, 4-5 April 2002) (in publication).

5 Case 106/77 Amministrazione delle Finanze dello Stato v Simmenthal Spa [1978] ECR 629.

6 Case 11/70 Internationale Handelsgesellschaft mbH v Einfuhr- und Vorratsstelle für Getreide und Futtermittel [1970] ECR 1125

7 Case 4/73 J Nold, Kohlen- und Baustoffgroßhandlung v Commission of the European Communities [1974] ECR 491. 
European Convention for the Protection of Human Rights and Fundamental Freedoms, signed in Rome on 4 November $1950 .{ }^{8}$ It follows that measures incompatible with the respect for human rights recognised and guaranteed in that way cannot be permitted within the Community. ${ }^{9}$ Moreover, the Treaty on European Union, signed in Maastricht on 7 February 1992, gave the force of law to these legal principles, establishing that: ${ }^{10}$

The Union shall respect fundamental rights, as guaranteed by the European Convention for the Protection of Human Rights and Fundamental Freedoms signed in Rome on 4 November 1950 and as they result from the constitutional traditions common to the Member States, as general principles of

Community law.

On the subject of citizenship rights, the Maastricht Treaty went even further: both in setting out the basic elements of citizenship of the Union, ${ }^{11}$ and in anticipating the adoption by member states of a charter "to strengthen or to add to the rights laid down in this Part".

And not before time, the Nice European Council of December 2000 concluded with the proclamation of the Charter of Fundamental Rights of the European Union. A compromise was reached: "yes" to the Charter of Rights in terms of political consensus; "no", for the moment, to the insertion of the Charter itself in the Treaty on European Union.

What we have seen, therefore, is an ideological anticipation of rights, the binding legal value of which will in time be fully revealed, and which every individual will be able to have protected in court, but only following the third major revision of the Treaty (after Maastricht and after Amsterdam); that is, after the adoption of the Draft Treaty establishing a Constitution for Europe. From a legal point of view, the difference between the "before" and the "after" of the future insertion of the Charter into the Treaty on European Union is subtle but important: before, the Charter provides the EC judge with an instrument with which to interpret the common constitutional traditions of the member states; after, it will instead be the common constitutional traditions that will constitute an instrument with which to interpret the Charter. This is not the place in which to analyse this difference; the fact is that the Charter has already been invoked in judgment in the first of the two senses indicated. In The Queen $v$ Secretary of State for Trade and Industry, ex parte

8 Case 44/79 Liselotte Hauer v Land Rheinland-Pfalz [1979] ECR 3727.

9 Case 5/88 Wachauf $v$ Bundesamt für Ernährung und Forstwirtschaft [1989] ECR 2609; Case C-260/89 Elliniki Radiophonia Tileorassi AE (ERT) v Dimotiki Étairia Pliroforissis (DEP) and Sotirios Kouvelas [1991] ECR I-2925.

10 Treaty on European Union (7 February 1992) 1757 UNTS 30615, art 6 para 2.

11 Art G sets out a series of rights including the right of every citizen of the Union residing in a state of which he or she is not a national to vote and to stand as a candidate at municipal elections in the member state in which he or she resides, under the same conditions as nationals of that state. 
Broadcasting, Entertainment, Cinematographic and Theatre Union, ${ }^{12}$ Advocate-General Tizzano in his opinion of 8 February 2001 urged the Court of Justice to consider that when fundamental rights are at issue, "the relevant statements of the Charter cannot be ignored".13

Rights; instruments for the protection of human rights; citizenship. As we have seen, the seed of a European constitution (in the essential sense of a law that protects rights) has already sprouted within the Community legal system.

The European Community, as we all know, operates within a larger entity, the European Union. The EU rests on three "pillars": one main pillar - the EC - and two smaller ones - common foreign and security policy, and police and judicial cooperation in criminal matters; with so-called "bridges" from one pillar to another. The EU has a two-limbed structure: one limb is the sphere of intergovernmental cooperation relating to common foreign and security policy; the other is the legal system of the EC, which as we have just seen is a highly complex structure, within which the individual occupies an absolutely central position.

Foreign policy in the EU is itself divided into two parts: commercial foreign policy, and foreign policy in the narrow sense; each governed in the Treaties by different but overlapping rules. The solution adopted in the field of foreign policy would therefore seem to lie halfway between an intergovernmental approach and communitisation. On the one hand we find the High Representative for the Common Foreign and Security Policy, who acts for the Council; and on the other, the Commissioner for External Relations, who is concerned above all with commercial relations. There is thus a whole field of commercial foreign policy that is to some extent communitised; and there is also foreign policy in the narrow sense, which is instead administered at the intergovernmental level. My concern here is with foreign policy in the narrow sense.

This is a necessarily brief, and certainly incomplete, account of the structure of the EU. But it is worth making, since without such a frame of reference the peculiarities of the European construction are not easily understood. I reaffirm at this point my conviction that the political integration of Europe is not limited by confederal or federal experience of the past, and reject the approach of Hughes and others since, who have tended to find in the concept of "confederation" an explanation of every intermediate association of states between the simple international union of states and the

12 Case C-173/99 The Queen $v$ Secretary of State for Trade and Industry, ex parte Broadcasting, Entertainment, Cinematographic and Theatre Union [2001] ECR I-4881.

13 See the similar views of Advocate-General Jacobs in Case C-50/00 Unión de Pequeños Agricultores $v$ Council of the European Union [2002] ECR I-6677 para 38. On the meaning and legal effect of the Charter, see A Manzella "Un Catalogo dei Diritti" [2001] 1 Il Mulino 34; Franz C Mayer "La Charte Européenne des Droits Fondamentaux et la Constitution Européenne" [2003] 2 Revue Trimestrielle de Droit Européen 175; Anna Rosa Cosi "The Protection of Fundamental Rights in the European Multilevel Legal Context" [2003] 1 La Comunità Internazionale 109. 
centripetal federal state. ${ }^{14}$ The concept of confederation is of more limited importance than that. It grew out of a desire to explain, at a time of prevailing statism, how states could by means of an international treaty commit themselves to the joint conduct of foreign affairs and defence, entrusting the management of them to a single organ, representative of the member states, and operating initially on the principle of unanimity and, more recently, qualified majority.

The EC/EU is almost the mirror image of a confederation: unlike a confederal legal system, which governs only the member states, a communitarian legal system also governs individuals and protects their rights; a confederal system has a monist structure with a central representative body, while the institutional structure of a communitarian system is pluralist; in a confederation the member states yield their sovereignty in foreign policy and defence to the confederation, which exercises it through the states, while in the EU foreign policy remains a state power, which it is nevertheless convenient to exercise jointly where the states themselves reach general agreement around a common position. ${ }^{15}$ As for a federal state, it is first and foremost a state: as such, its public administration is distributed throughout the entire national territory: something that Europe will probably never have, not even after having attained political integration.

Let us return now to the first of the questions I raised at the outset of this paper. When, in legal terms, will the united Europe emerge? I indicate here three new stages in the process of integration.

Stage 1: Foreign policy is integrated into the Community method. In general terms, the European Union is a simple container, an entity which cannot be identified with the Communities but comprises them, as well as the two lateral pillars. It is a European Union without legal personality, nor its own organs of government (if one excludes the Council of Europe), nor its own legal system distinct from that of the European Community. The EU is essentially a connecting system for the various Communities, operating on the basis of cooperation. If anything, its architecture would seem to reveal a secret desire among the member states, or some of them, to thwart any future European integration. The thing to do in light of this is as simple (remembering that simple does not mean easy, nor currently possible) as it is pivotal for the future of Europe. The thing to do is to remove the disjunction between the EU and the EC by adding foreign policy and defence to the competencies of the communitised Europe. Only then will Europe be able to speak with a single and genuinely authoritative voice.

Stage 2: Majority decision-making in foreign policy and defence. It is highly probable that the member states will wish to preserve for as long as possible the principle of unanimity in important matters of foreign policy. Unanimity, Tomaso Perassi explained, ${ }^{16}$ gives every member state the

14 Christopher Hughes Confederacies: An Inaugural Lecture Delivered in the University of Leicester 8 November 1962 (Leicester University Press, Leicester, 1963).

15 On these various aspects of "classical" Confederations, in comparison with the characteristics of the EU, see A La Pergola "Sguardo sul Federalismo e i suoi Dintorni" (1992) 3 Diritto e Società 491-519.

16 Tomaso Perassi L'Ordinamento delle Nazioni Unite (Cedam, Padua, 1957) 25. 
possibility of blocking through its negative vote a decision which it considers contrary to one of its interests. The negative vote of a single state prevents a proposal from being adopted by the group, even if approved by all other states. The thing is, however, that decisions taken in this way can never be truly durable. While politics (understood as a way of giving life to contrasting views) divides by its very nature, a unanimous vote masks a kind of "antipolitics", where any decision that divides - that is, every political decision - is avoided at all costs. The member states of the EU will in time realise that foreign policy becomes unmanageable when entrusted to an organ that makes its decisions on the basis of unanimity, and will return to voting by majority (the alternatives of withdrawal from the Treaty and of secession being totally out of the question: European integration is a one-way street).

Stage 3: The European Parliament manages foreign policy. This change will face even greater resistance, since the member states will fiercely oppose the idea of extending the European Parliament's powers of decision and control in line with the expanded Community competence in foreign policy and defence. Their opposition to the idea of involving the European Parliament in the management of foreign policy will undoubtedly be based on the oft-repeated argument that the ratification of Community decisions on as highly-charged a subject as foreign policy must remain the role of the national parliaments, since it is in the national parliaments, rather than in the European Parliament, that the true democratic centre of gravity of European integration resides.

Nevertheless, this argument can never be a strong one. It will be nothing but a last-ditch attempt to protect states that will by then be well aware that associating the European Parliament with the conduct of foreign policy is the decisive step towards the goal (yearned for by some, opposed by others) of European integration: that is, the end of the independence of the member states, and their absorption into a general legal system (even though not of a federal state, or rather, even though not of a state) corresponding to the whole of their territories.

It is clear that the process of integration will not be concluded, at a procedural level, without a parallel adjustment of the institutional structure of the Community. Currently, at the centre of the communitarian system - and by "centre" I mean a body capable of receiving the impulses of the member states and working them into a framework of general interests held by the collective - we find the Commission. This deliberative and executive body - a cabinet for the Community - is something the Community could not easily do without. The Commission operates as a "neutral zone" among the disparate and often contrasting national interests (particularly in the area of competition), and as such is essential now, and will be in the future, to the good functioning of the Community machine. The Commission, together with the Court of Justice, has been the chief driver of the process of integration, and an essential driver before the states came to understand that the national interest and the common interest are not mutually exclusive, but are - ultimately - allies. In this respect, the Commission is needed now more than ever before, to hold together a Community made up not of different peoples, but of different worlds. When Community life had no "political" dimension in the proper sense of the word, the Commission could fulfil this unifying function. 
Starting with the Maastricht Treaty, however, the EU has begun to assume a strongly political character; destined, moreover, to grow over time. The institutional balance of the EU is moving, step-by-step and almost inadvertently, in ways that it is not possible to clarify here.

Having answered, albeit in broad terms, the question of when, legally speaking, the process of European integration will be completed, we now face another, inevitable question of much greater range and depth: namely, whether Europe will be integrated. I pose it tentatively, well aware, among other things, that the evolution of political structures is not a matter of simple arithmetic. But it is worth venturing an answer.

The typical response is "Yes, Europe will be integrated, but only in the presence (dies incertus an et quando) of a powerful 'federator'"; and by this is meant a serious and imminent danger which threatens Europe directly and demands centralised government as the only way of confronting the situation. In the absence of such a danger, the argument goes, the European construction is destined to remain one of economic cooperation among states, albeit close and highly sophisticated economic cooperation. What sort of danger we might be looking at is never articulated openly, leaving the imagination to run to hypotheses as catastrophic as they are unlikely: it could be the presence of some external threat which jeopardises the cultural identity of Europe, if not peace itself (this is the "enemy at the gates" hypothesis, which in turn raises the idea of "fortress Europe"); or an attack in grand style of international terrorism; or a tidal wave of migration, forcing governments to put up the shutters on Europe. Scenes worthy of a horror film. Stupidities. If this is what European integration means, the birth of the united Europe is destined never to happen; and we will be all the better for it.

I would observe instead that there is already in Europe a powerful federating force with a strongly pacific character: the internal market. I should note, however, that when I speak of the common market as the principal integrating force within the countries of the EU (a force that in the near future will be as potent as it has been in the past) I do not have the slightest intention of being understood to sustain a thesis that I consider utterly unsustainable: namely, that political integration and a common market are corequisites. The thesis goes like this: if it is true that the process of integration among previously independent states is necessarily accompanied by the formation of a common market, so (this is the unsustainable bit) must the opposite be true: political integration must follow, sooner or later, the formation of the common market. This argument I consider frankly wrong. While a desire for political integration has already been satisfied when a state proceeds to the creation of a domestic market, in the case of a regional market, political integration does not figure - as a rule - in the intentions of the signing states; in fact it is directly rejected in a number of treaties. Furthermore, if the thesis were true, we could expect to find as many political unions as there are regional markets operating and overlapping in the world today.

Admittedly, the economic integration that has occurred in Europe under the auspices of the EC can be distinguished from other similar experiences by two characteristics: the drive towards political unity, and the frameworks and legal structures necessary for the formation of the integrated 
market. None of the regional markets currently in operation - not Mercosur, nor Nafta, nor the similar African ones - was born as a means to the end of an ever closer union among the peoples of the states parties, while that is precisely the function assigned to the European Economic Community right from the start; where the High Contracting Parties proposed in the Preamble of the Treaty of Rome to "lay the foundations", through the institution of a common market, "of an ever closer union among the peoples of Europe". ${ }^{17}$ The European idea stands at the dawn of the common market, it constitutes its background and its frame of reference. This is the same "European idea" of which the Preamble of the Single European Act speaks in its fourth paragraph, when it recognises the need for it to correspond to "the wishes of the democratic peoples of Europe". ${ }^{18}$ This is the way in which the common market and economic and monetary union have grown and developed, even in the face of a thousand obstacles and delays, propelled by the conviction that the goal to be reached, the goal which gets closer step-by-step, is "the construction of the future Europe". ${ }^{19}$

The second characteristic that distinguishes European economic integration from other experiences is the fact that the ever greater degree of economic integration, which has now reached a peak that will not easily be equalled, has made use of the combined and contemporaneous action of structures and legal tools already provided for (some in only embryonic form) in the founding Treaty. These structures and tools - the Commission, the Court of Justice, the preliminary reference, the direct effect of community norms, and the avenues of challenge available to individuals - have operated as a growth factor in the process of integration.

It is these two characteristics, an ideal and a technique, one fused to the other, that have made the common market a potent federating force, the natural consequence of which is the political unity of Europe. Let us see how.

My hypothesis (a hypothesis sustained also by the functionalists, and shared at least in part by G Federico Mancini ${ }^{20}$ is grounded in the firm belief that the absence of political integration in Europe has a high cost in terms of development and economic growth. This, I suggest, is true from two perspectives. From the internal point of view, it is a fact that economic integration has been realised with respect to monetary policy, but not fiscal policy. At the level of monetary policy, we find a sole supranational authority, the European Central Bank, bound to conserve the stability of prices while maintaining a low rate of inflation. Fiscal policy instead remains broadly the responsibility of the national governments, within limits imposed by the Stability and Growth Pact. As for indirect taxation, which impacts immediately on the end consumer, the burden is very different from country to country, and the harmonisation administered by the Commission has shown itself to be weak,

17 Treaty on European Union, above n 10, art 1.

18 Single European Act (1986) OJ L169/87.

19 Treaty on European Union (7 February 1992) 1757 UNTS 30615, preamble.

20 G Federico Mancini "Argomenti per uno Stato Europeo" [1998] 1 Sociologia del Diritto 7-27. 
difficult to achieve, and able to affect rates, smoothing out the worst inconsistencies, but not also the prices of goods themselves. ${ }^{21}$ It is obvious that the absence of uniform, and therefore unitary, fiscal policy seriously distorts competition. Indirect taxation yields different prices for a single good on the Community market, creating a deep imbalance in the "open market economy with free competition" that inspires or should inspire - by virtue of articles 4 and 98 of the EC Treaty - the actions of the Community and of the states in the field of economic policy. Economic integration as currently realised in Europe is a rather one-legged affair.

If, having renounced their monetary power, the member states also decided to renounce their power in fiscal matters, then economic policy would be managed no longer at a national level, but rather at a European level. A single economic policy presupposes a single general policy, because the trends of general policy are intertwined with economic policy; and a single policy in Europe presupposes a single European government to develop and apply it.

On the other hand, it is undeniable that in the competitive coexistence of economies, whether they be national or regional, the trust of international markets plays a very important role (whether positive or negative). ${ }^{22}$ The credibility of an economy on the world market is a function of two variables: its productive capacity, and the politico-diplomatic authority enjoyed by its government and legal system. ${ }^{23}$ Only a great authority of Europe as a whole, greater than that of the most "powerful" of its member states, is truly capable of exploiting the potential of European economic integration, ensuring that its supply of goods, services, and capital is matched by adequate external demand.

It seems to me, moreover, that this hypothesis of the market as a federating force can be reconciled with the widely-held belief that economic globalisation should be accompanied by some form of political globalisation. If some of the most serious problems that globalisation is alleged to have caused (attracting criticism and opposition of various kinds - which themselves are globalising and institutionalising) derive from the current situation of "governance without government", then

21 The instability of the harmonised EC system in respect of indirect taxation is evident upon a simple reading of two recent judgments of the Court of Justice: one in Case C-345/99 Commission of the European Communities v French Republic [2001] ECR I-4493, the other in Case C-40/00 Commission of the European Communities v French Republic [2001] ECR I-4539, both of 14 June 2001 and both concerned with article 17(2) of the Sixth Council Directive of 17 May 1977, 77/388/CEE, on the harmonisation of the laws of the member states relating to turnover taxes (common system of value added tax: uniform basis of assessment): OJ 1977 L 145, 1, in the version resulting from Council Directive 95/7/EC of 10 April 1995 amending Directive 77/388 and introducing new simplification measures with regard to value added tax.

22 On this point see Yves L Doz "Politiche dei Governi e Settori Industriali Globali" in Michael E Porter (ed) Competizione Globale (ISEDI, Turin, 1987) 243, 294 (original title Competition in Global Industries (Harvard Business School Press, Boston, 1986)).

23 And, Gaetano Quagliariello observes (rightly, in my view), military authority: "O l'Europa si Arma o Resteremo Sempre Nani" (4 April 2003) Il Messaggero 1. 
there should be as much of a need for unitary government on the regional scale as on the world scale.

But there is a problem. Many of the most learned commentators (especially German commentators) insist that European integration is for now an impossible goal, because the fundamental premise - a single European people - is lacking, and because only a single people can give itself a constitution. ${ }^{24}$ Europe, it is said, is an agglomeration of ethnic groups, a collection of nations pervaded by patriotic sentiments and jealous of their diversity, a mixture of peoples lukewarm on any suggestion of amalgamation, even after economic integration has been achieved; proud, separated by language, history, culture, and sometimes even by religion (if one thinks about the blood spilt in Northern Ireland).

But this is not the reality. We have come a long way since the 1950s and 60s, when the states of Europe were rigidly defensive of their own sovereignty; petty, blind, aggressive, self-centred; when De Gaulle pushed for a Confédération des Patries; when scrawled on the interiors of British trains was the saying "God made man and He was happy; God made woman and He was happy; God made De Gaulle and he is still crying!". The ideology of europeanism is becoming ever more widespread and deeply rooted among young Europeans. There is even some indication - God forbid - of the development of a kind of European nationalism.

The emergence among the people of Europe of a politics that can be described as truly "European", rather than merely national, is only a few years off. European politics will in turn strengthen the identity of the European people; it will counter the myopia of national interests and jealousies; it will help to reduce the democratic deficit that has always afflicted the Community; it will allow the European populace to assume a dominant and influential role in the business of the Union, through a Parliament that will at long last have real decision-making power, including the power of approving or rejecting proposals to modify the Treaties. This will be the revolution on the road to European integration: only then - and not an instant before - will the passage from legitimation by rights to democratic legitimation be complete.

What I have just said about the common market as a potent federating force, and in particular about the fact that a European people is already alive and visible and supported by a comprehensive body of fundamental rights, does not mean at all that European political integration is inevitable, or that it is simply a question of waiting for it to happen. On the contrary, there are many obstacles on the road from economic Europe to political Europe. One example is the close alliance between the

24 This is the view, for example, of Dieter Grimm in the third section of his most recent book Die Verfassung und die Politik: Einsprüche in Störfallen (Beck, Munich, 2001); and also of Peter Häberle "Per una Dottrina della Costituzione Europea" (1999) 19 Quaderni Costituzionali 3, especially para 1.2.1, where he discusses the absence of a public European dimension founded on a set of minimum common values and principles; see also, on the role of the populace in the formation of a democratic constitution, C Pinelli Il Momento della Scrittura: Contributo al Dibattito sulla Costituzione Europea (Il Mulino, Bologna, 2002) 79. 
United Kingdom and the United States, which undoubtedly inhibits the formation of a Community foreign policy distinct from that of America. Another might be the eventual entry into the EU of Turkey, whose culture is markedly different from that of the existing "Europe" (if not necessarily incompatible with it). But perhaps the biggest obstacle is the ballast that weighs down every process of integration: the resistance of the political and legal elites of the individual states to the sudden and comprehensive re-sizing of their role and status which would accompany the end of national sovereignty; resistance that is perhaps more serious and recalcitrant in Europe than elsewhere. Heads of state and of government, Ministers, and superior-court judges of the member states of the $\mathrm{EU}$, who today represent their states in various international institutions, will lose that privilege when the process of European integration comes to fruition. The thing they fear most is not so much the reduction of state power - after all, it has been a continuous and increasingly marked feature of all five Treaties since 1957, to the point where no less a constitutionalist than Anthony Bradley questions whether the famed sovereignty of the Parliament at Westminster still exists in fact, ${ }^{25}$ and Sabino Cassese and Giuseppe Guarino speak openly of the European states as "post-states". ${ }^{26}$ What those elites fear most is that state power will become so highly circumscribed that their respective states can no longer be described as "states" at international law, nor they themselves as "state" officials. What they fear, in other words, is the loss not only of the noun in the expression "state power", but also of the adjective. The governments of the various European countries, all inheritors of proud political and cultural traditions, are undoubtedly anxious to cultivate deep and diffuse feelings of national pride as a way of preserving their status and the prerogatives that go along with it. Reluctantly will they sign the death warrants of the nation states of Europe, short of being constrained to do so by the force of economics.

How much time might be needed before we will see a politically united Europe, no-one can say. But Europe cannot wait indefinitely, its people are dreaming happy dreams of what might be. The political integration of Europe is not some vague future event, it is no longer a night without stars; it is close to realisation. But the answer to the "when?" question is not something that can be determined objectively. I see it ultimately as a choice: one of Goethe's "elective affinities".

25 "The Sovereignty of Parliament - in Perpetuity?" in Jeffrey Jowell and Dawn Oliver (eds) The Changing Constitution (Clarendon Press, Oxford, 1994) 79-107.

26 Giuseppe Guarino Il Governo del Mondo Globale (Le Monnier, Florence, 2000); Sabino Cassese La Crisi dello Stato (Laterza, Bari, 2002). 